\title{
A MULTIDIMENSIONALIDADE DOS CONFLITOS E SEUS EFEITOS NA PRODUÇÃO DE POLÍTICAS (DE “TERREIROS/"CRISTOFASCISTAS"): ALGUMAS RESPOSTAS, OUTRAS QUESTÕES ${ }^{1}$
}

\author{
THE MULTIDIMENSIONALITY OF CONFLICTS AND THEIR EFFECTS \\ ON THE PRODUCTION OF POLITICS (OF "TERREIROS"|"CHRISTOFASCISTS"): \\ SOME ANSWERS, OTHER QUESTIONS
}

Ana Paula Mendes de Miranda

A possibilidade de responder, e agradecer, aos comentários dos colegas a um artigo produzido durante a pandemia é um privilégio ímpar. Submetidos ao isolamento, provocado pelas regras sanitárias, e aprisionados a uma nova rotina de trabalho (o "remoto"), que nos afastou do convívio dos encontros presenciais, perdemos a chance de aprimorar os artigos em debates para depois publicá-los. O artigo "A 'política dos terreiros' contra o racismo religioso e as políticas 'cristofascistas', que abre este número da Debates do NER foi pensado e produzido em plena pandemia ${ }^{3}$, quando foram suspensas as atividades de pesquisa de campo porque os terreiros interromperam suas atividades durante muitos meses. Desde que comecei a pesquisa, em 2008, essa foi a primeira vez que fiquei totalmente fora do contato face a face com meus interlocutores.

1 Como citar: MIRANDA, Ana Paula Mendes de. A multidimensionalidade dos conflitos e seus efeitos na produção de políticas (de "terreiros"/"cristofascistas"): algumas respostas, outras questóes. Debates do NER, Porto Alegre, ano 21, n. 40, p. 211-234, 2021.

2 Doutora em Antropologia Social, professora do Programa de Pós-Graduação em Antropologia da Universidade Federal Fluminense, Brasil. E-mail: anapaulamiranda@id.uff. br. ORCID: https://orcid.org/0000-0003-1007-6714.

3 Escrito a convite da Profa. Lia Zanotta Machado para integrar o dossiê "Anthropology in times of intolerance: challenges facing neoconservatism”, organizado por ela e Antonio Motta, na revista Vibrant (Miranda, 2020). Publicado neste debate com revisóes, a convite da Profa. Stefania Capone.

Debates do NER, Porto Alegre, ANo 2I, N. 4O, P. 2 I I-234, AGO./DEZ. 202 I 
Assim, voltar ao que escrevi, tendo em mente as interpretaçóes e perguntas dos colegas, abriu caminhos para pensar outras frentes de pesquisas e futuros artigos. Agradeço as argutas e atentas observaçóes, mas náo será possível tratar de todas. Optei por construir uma argumentaçáo que dê conta dos aspectos que orientaram o artigo original - pensar o significado do ressurgimento da "intolerância" no contexto atual, marcado por explicitação de pensamentos "neoconservadores" - focando nos conflitos nos quais os religiosos de matrizes afro são vítimas de agressôes provocadas por grupos com religiosidade de perfil evangélico-pentecostal, que se tornaram cada vez mais graves nos últimos anos.

\section{A Dimensão ÉTNICO-RACIAL}

Como ponto de partida penso ser importante delimitar o que tenho chamado de "conflito de natureza étnico-racial-religiosa". Trata-se de uma chave importante para explicitar alguns pressupostos teórico-metodológicos que têm orientado minha pesquisa. Minha trajetória tem se voltado a compreender como distintas formas de intervençâo de agentes públicos produzem efeitos nas relaçóes sociais quando se trata de administrar conflitos e executar políticas públicas, no "fazer-se" do Estado. Foi assim que cheguei à Comissão de Combate à Intolerância Religiosa (CCIR), em 2008, no Rio de Janeiro, levada por um oficial da polícia militar, o ex-comandante da força Cel. Ubiratan de Oliveira Ângelo, à época meu colega na universidade em que lecionava, que fora convidado para ajudar a coordenar a segurança do evento que seria realizado pela primeira vez - uma caminhada em Copacabana. Simbolicamente, entrei no "campo" das religiōes afro a partir do Estado, buscando compreender como as moralidades dos agentes públicos afetavam a recepçáo das denúncias dos afrorreligiosos. Progressivamente foi se delineando um contexto de imersão na perspectiva dos religiosos diante da (in)ação do Estado, o que me levou a problematizar os modos de se fazer política nesse campo empírico, tomando por referência como os religiosos e os militantes pensavam e exerciam suas práticas. 
Em um debate no Grupo de Trabalho de Enfrentamento à Intolerância e Discriminação Religiosa para a Promoção dos Direitos Humanos ${ }^{4}$, organizado pela Secretaria de Estado de Assistência Social e Direitos Humanos do Rio de Janeiro, lembro-me de ver Lúcia Xavier ${ }^{5}$ argumentar veementemente que o problema não era a perseguição religiosa em si, mas uma perseguição provocada pela discriminação racial, que precedia à demonização das matrizes afro-brasileiras. Ao longo da pesquisa de campo foi se tornando evidente que a categoria "conflito religioso"' não era suficiente para descrever os casos narrados pelos interlocutores. Tudo apontava para o fato de que o "problema" era de outra ordem, a religiáo é atacada porque ela "é de negros"7. A dimensão étnico-racial aparecia nas narrativas como a principal causa para as violências praticadas contra os terreiros e seus adeptos.

4 Era uma das "especialistas" convidadas a integrar o GT, juntamente com as professoras Thula Rafaela de Oliveira Pires (PUC-RJ) e Aureanice de Mello Correa (UERJ). A profa. Christina Vital da Cunha participou como "representante de organização de direitos humanos" - Instituto de Estudos da Religião - ISER.

5 Ativista de direitos humanos, fundadora da ONG Criola, ekedi do terreiro Ilê Omi Oju Arô, hoje liderado por Adailton Moreira, herdeiro de Mãe Beata de Iemanjá.

6 Conflito, aqui, está inspirado na teoria sociológica de Simmel (1964) no que diz respeito à funcionalidade positiva do conflito, como forma de interação que explicita e, em certos casos, "resolve" tensões e dualismos. Esse modo de pensar é oposto ao que se costuma pensar no Brasil sobre o conflito, como uma situação negativa, que deve ser suprimida imediatamente, muitas vezes com a intervenção dura e forte do Estado. O conflito aqui é o contexto que permite compreender a constituição dos atores sociais, como propóe Touraine (1973). A escolha metodológica de pesquisa tem sido orientada pela análise situacional (extended case method), proposta por Gluckman (1987) e Van Velsen (1987), quando o estudo da dimensão política dos casos de conflito social permite perceber como as narrativas podem ser decompostas no que tange às relaçóes sociais existentes, e não como mero estudo de caso para ilustrar empiricamente os argumentos dos atores.

7 Saliento que até hoje não conheço casos de agressóes a centros kardecistas. Os relatos que tenho acompanhado desde 2008 mostram que o foco está nos centros e terreiros de umbanda e candomblé, com toda a sua diversidade de configuraçóes. Não posso deixar de registrar como o kardecismo está associado a uma abordagem racializada, eurocêntrica e evolucionista.

Debates do NER, Porto Alegre, ANo 2 I, N. 4O, P. 2 I I-234, Ago./DeZ. 202 I 
Compreender os conflitos significa uma escolha metodológica de pensar universos culturais em disputa, lutas que pressupóem relaçóes de poder, nas quais as matrizes afro estão em posição assimétrica de inferiorização, por conta de sua histórica perseguição e demonizaçăo protagonizada pelo Estado e pelas Igrejas cristás. Tal escolha se dá em oposição à ideia de "guerra", que acredita em uma simetria entre os sujeitos envolvidos, inexistente empiricamente no caso.

Neste aspecto retomo o artigo de Ronaldo Almeida que menciona a revisão de posição de Luiz Eduardo Soares (2019), que deixou de lado o argumento sustentado nos anos 1990 - "guerra religiosa" (Soares, 1993) -, para tratar da belicosidade dos conflitos religiosos e da hegemonia política do neopentecostalismo. Considero que a revisão do uso do termo por Soares náo foi suficiente para entender os lugares desses sujeitos no campo religioso. $\mathrm{O}$ autor analisa o "campo religioso brasileiro" sem considerar o lugar das religiôes de matriz africana, que são excluídas desse campo, o que faz com que não se enfrente a dimensão racial no conflito (evangélicos versus afro-brasileiros). $\mathrm{O}$ autor pretende compreender as "revoluçoes" do "campo religioso brasileiro", e sua relação com as "grandes mudanças sociais", mas desconsidera que a perseguição é afetada pelo viés racial. Tal fato parece uma limitação para se pensar os processos de vulnerabilizaçáo e vitimização. O lugar das religiốes de matriz africana no campo religioso náo pode ser medido pelo seu baixo percentual de registro no Censo do IBGE, cuja pergunta não possibilita uma resposta múltipla ${ }^{8}$. Se o argumento da expansão do neopentecostalismo aconteceu pela criação de um antagonismo em relação às religiôes de matriz africana, como afirma Soares, é preciso analisar as nuances e significados dessa estabilidade ( $0,3 \%$ da população se declarou dessa forma nos Censos do IBGE 2000 e 2010) ${ }^{9}$. O segmento que está sob ataque - religióes de

8 Há um pressuposto implícito de que a identidade religiosa é única. Escolhendo uma, não é possível escolher outra. Na prática, sabe-se que o pertencimento religioso é mais complexo.

9 Ressalto que esses dados são analisados separadamente da categoria "espírita". Referem-se apenas aos dados classificados como "afro-brasileiros". Lembro ainda da campanha "Quem é de Axé diz que é", que surgiu na época do Censo de 2010 para estimular que os religiosos assumam publicamente sua identidade religiosa. 
matriz africana - representa um universo complexo e diverso (Catimbó, Tambor de Mina, Xangó, Candomblé, Umbanda, Batuques etc.), disperso pelo território nacional que registrou oficialmente crescimento de adeptos naquele momento, fato também observado entre os que se declaram sem religião. $\mathrm{O}$ segmento que registrou retração foi o católico. Tais dados nos fazem refletir entâo porque o debate sobre o campo religioso exclui dele um ator fundamental no debate público.

Concordando com Ronaldo de Almeida, de que raça é relação, penso que a pergunta que ele traz - "como tratar a violência religiosa como racista quando praticada por traficantes evangélicos que também agenciam um discurso de vítima "do sistema" e do racismo da sociedade brasileira?" - é fundamental para evidenciar como as políticas públicas no Brasil são racializadas, mas seus efeitos são distintos conforme os sujeitos-alvo da discriminação.

Para construir minha resposta trago ao debate o artigo da Profa. Luena Nascimento Nunes Pereira (2020), sobre a branquidade e descentramentos nas Ciências Sociais. Refiro-me à crítica que ela faz à ideia de "brasilidade", que se caracterizou pela "ocultação e invisibilização das marcas étnicas de africanidade e de indigenidade" (2020, p. 9), e foi construída por uma institucionalização da miscigenação, por meio de políticas oficiais de branqueamento, que tiveram como consequência a produção de um "racismo cordial", que resultou, por sua vez, no "apagamento e minimização dos conflitos".

Os "traficantes evangélicos" podem agenciar o discurso de "vítimas do sistema”. Na minha experiência de pesquisa, tal discurso também é acionado por profissionais da segurança pública (policiais, guardas etc.). Ao equiparar essas falas não pretendo considerá-las "falsas". Porém, considero que não podemos pensar que estejam na mesma posição (em termos de simetria) às falas dos afrorreligiosos. Quando se pronunciam como vítimas, apresentam evidências de que seus direitos são cotidianamente violados, mas nem por isso utilizam força armada para lidar com os ataques. O que se vê etnograficamente é que os "traficantes evangélicos", mesmo na condição de "vítimas do sistema", utilizam de seu controle territorial armado para oprimir os afrorreligiosos. Nesse sentido, penso que é preciso entender o 
lugar ocupado pelos "traficantes evangélicos" como equivalente ao dos profissionais de segurança, já que constituem suas identidades públicas a partir de suas interfaces com os poderes públicos constituídos, num jogo político-econômico de tolerância e/ou conivência com o status quo local. Tal interação é constitutiva do que temos chamado de "domínio armado"10 (Miranda, Muniz, 2018). No caso dos territórios em disputa no Rio de Janeiro, trata-se de um modo de gerir e governar que náo respeita a soberania e a legitimidade dos sujeitos que lá estáo, no caso analisado, o "povo de terreiro". Os discursos vitimizados dos "traficantes evangélicos" não os constituem como "vítimas" (Sarti, 2011, 2014), ou seja, como sujeitos políticos que reivindicam o status de cidadania que pressupóe um reconhecimento oficial de que há uma violaçáo de direitos. Isso ocorre com os afrorreligiosos por conta da mobilizaçáo política que produziu a emergência da categoria "racismo religioso" para dar conta dos problemas que trazem à público. São as estratégias da "política de terreiros" que têm transformado um problema social, o conflito religioso, em um problema público (Cefaï, 1996) - o conflito étnico-racial-religioso, que demanda um tratamento especializado por parte dos poderes públicos, instituiçóes e movimentos sociais (Miranda, Corrêa, Almeida, 2019).

É a denúncia da dupla violaçẫo - liberdade religiosa e intolerância/racismo religioso - que constitui os afrorreligiosos como sujeitos de uma política que designo como a política dos "terreiros", que só emerge na cena pública no quadro de racializaçâao resultante da Constituição de 1988 e do Estatuto da Igualdade Racial. Um dos efeitos disso é a explicitação das contradiçôes históricas das políticas públicas brasileiras, que só se reconhecem racializadas quando se dirigem aos negros e indígenas. Quando voltada aos brancos é pensada apenas como "política". Assim, a "arte ou ciência de governar" passa a ser interpretada, negativamente, como uma astúcia "maquiavélica" voltada a atender interesses (sempre considerados de modo pejorativo), no caso, dos sujeitos racializados - os "negros". A "branquitude" produz uma opacidade

${ }^{10}$ A ação pode ocorrer em conjunção ou em disputa com os "milicianos" ou as forças de segurança. 
por não permitir que a racialização da política seja percebida e por não deixar identificar os sinais da racialização da religiâo. É assim que a inferiorização das religióes afro se produz na supremacia branca e cristá. É isso que os afrorreligiosos tentam denunciar quando buscam o Estado. Eles não necessariamente acreditam que terão algum resultado, mas ao fazê-lo pretendem exercer seu direito de existir.

Outro aspecto relevante tem sido analisado por Rosiane Rodrigues de Almeida (2015), ao se dedicar a compreender como os militantes dos movimentos negros lidavam com os casos de "intolerância religiosa”, a fim de entender em que medida as variáveis cor/raça/religião seriam, ou não, temas imbricados e complementares neste contexto. Tal questão, aprofundada pela autora para refletir sobre como se deu a entrada dos neopentecostais na luta antirracista, evidenciou que esse processo tem resultado em um silenciamento dos afrorreligiosos e no reordenamento do jogo das relaçóes raciais, por meio do acionamento do "colorismo" e da controvérsia do "embranquecimento" dos terreiros" (Almeida, 2015), para mais uma vez tirar de cena a agência dos religiosos de matrizes afro. A autora destaca que é por meio dessa agência que a vitória no Supremo Tribunal Federal no caso da sacralização de animais foi conquistada, tema que também é mencionado no texto de Ari Pedro Oro neste debate. Oro "testou" as categorias construídas no meu artigo considerando o contexto do Rio Grande do Sul, estado que produziu sobre si uma autoimagem de um "estado branco, colonizado e habitado por imigrantes europeus e por gaúchos, invisibilizando e mesmo excluindo os negros e os indígenas”.

Ari Pedro Oro argumenta que o racismo existente no estado está diretamente relacionado ao conjunto de mobilizações e articulaçôes tanto em recintos sagrados, quanto no espaço público e estatal, concordando com o argumento de que as "políticas dos terreiros" são geradoras de "energia para ação e a potência para defender publicamente os seus direitos". O autor também concorda que as políticas "cristofascistas" constituem "manifestaçóes de ideologias raciais de discriminação étnico-religiosa enquanto prolongamento na atualidade de posturas e práticas próprias do sistema escravocrata". 
O conflito de natureza étnico-racial-religiosa sobre o qual temos nos dedicado, aponta que a disputa de "negros contra negros" é resultado e produzido pelo "auto-ódio" (Almeida, 2019), entendido como uma categoria nativa, utilizada por segmentos do Movimento Negro para denunciar o efeito que o desejo de embranquecer (na cor da pele, nos costumes, nos hábitos) promove entre os negros.

É o "auto-ódio" que permite, etnograficamente, entender como o acionamento das políticas "cristofascistas" podem operar em diferentes planos, seja entre os "traficantes evangélicos", seja na "política de Deus acima de todos", fazendo ter sentido a nomeação de Sérgio Camargo para a Fundação Cultural Palmares, como apontado por Elina I. Hartikainen, em seu comentário. A estratégia que coloca "negros contra negros" é parte das redes tecidas entre o cristianismo evangélico militante e as ideologias raciais arraigadas, que seguem estruturando éticas e práticas do Estado e da sociedade brasileira.

Tendo como base a pesquisa de campo realizada em Salvador (BA), Elina aponta como o surgimento de ataques violentos às religióes afro-brasileiras não pode ser separado dos fundamentos políticos. Ela destaca o protagonismo de um cristianismo evangélico mais militante e violento na constituição de agendas políticas cristãs evangélicas como base do populismo antidemocrático do governo de Jair Bolsonaro, que resultou no desmantelamento e reorganização das agências e programas do governo federal dedicados à proteção dos direitos humanos em geral, bem como dos direitos religiosos dos praticantes afro-brasileiros em particular. Mas a autora sinaliza que há luz no fim do túnel ao dizer que essa agenda política cristã "terrivelmente evangélica" teve um efeito oposto ao produzir um senso de justificação política, em vez de moral, diante da impunidade vigente entre os perpetradores de ataques às religióes afro-brasileiras desde sua ascensão ao poder.

O reconhecimento oficial do "racismo religioso" e seus usos funcionam, portanto, como uma postura crítica e resistente à crescente influência dos discursos sobre os valores cristãos (preferencialmente evangélicos, mas não só) na política brasileira. A mobilização política representa que a violação 
desses direitos prejudica o projeto político mais amplo - uma igualdade religiosa e racial para todos os brasileiros.

A questão trazida por John F. Collins sobre a crítica que o rastafarianismo faria ao candomblé foge ao meu universo empírico. $\mathrm{O}$ autor insere o movimento no campo das religióes afro-brasileiras em Salvador, mas em todas as pesquisas empíricas que realizei (Rio de Janeiro, Distrito Federal, Sergipe e Alagoas) esses atores não apareceram como parte da cena pública na luta contra a "intolerância"/"racismo" religiosos. As disputas que encontrei foram no campo do candomblé (entre as naçóes), entre umbanda e candomblé, dentre outros antagonismos e diferenciaçōes (por exemplo, os malês), que sinalizam como o universo afro-brasileiro se pensa e se constitui como um todo, a partir da fragmentaçáo interna. Posso dizer que encontrei mais líderes religiosos do candomblé argumentando contra o discurso de mestiçagem e em favor de uma valorização das "raízes africanas", do que apoiando a mestiçagem - discurso mais associado aos líderes umbandistas com quem pude conversar. O que tenho percebido sobre as fronteiras identitárias internas tem auxiliado a compreender o campo das matrizes afro, mas não considero que permita uma análise sobre um discurso "consensual" sobre o tema da mestiçagem, que não foi uma questão para a pesquisa. Seria preciso um olhar direcionado a este assunto, o que não foi feito. Do que pude observar, há uma resistência e uma negaçáo quando se trata de mestiçagem ${ }^{11}$, mas há também uma controvérsia importante sobre o sincretismo, que nem ouso explorar, que é fruto de uma interação de religiosos com as militâncias do Movimento Negro. Há que se lembrar, ainda, que nessa interação o próprio movimento incorporou sinais diacríticos das matrizes afro-brasileiras para defender uma identidade de "negritude" como marcas de empoderamento. A religiáo teria deixado de ser pensada como o "ópio do povo"? Esta provocação talvez não possa ser respondida com os dados de que disponho, mas certamente o trabalho de Mariana Ramos de Morais

${ }^{11}$ Lembro que o tema segue até hoje sendo ensinado nas escolas como um "mito" fundador da nação brasileira, apesar dos esforços de sua desconstrução.

Debates do NER, Porto Alegre, ANo 2 I , N. 4O, P. 2 I I-234, AGo./DeZ. 202 I 
(2012) nos permite compreender como a relação entre o Movimento Negro e as religióes afro-brasileiras mudou nos últimos anos.

Discordo da interpretação que Collins fez do meu artigo, segundo a qual haveria uma "orquestração" entre evangélicos e traficantes. Digo exatamente o oposto. Demonstro como há uma teia complexa constitutiva de uma política mais ampla, que envolve distintos atores estatais, na perpetuação do racismo. Minha pesquisa está voltada a etnografar as ações e reações dos afrorreligiosos aos ataques sofridos e suas consequências, no campo da política. Não poderia falar sobre como pensam e sentem os evangélicos se não os tenho como interlocutores de pesquisa ${ }^{12}$. Para saber o que pensam, leio e cito a produção dos muitos pesquisadores que atuam nesse universo empírico. Aprendi que quando se estuda conflito não é possível uma abordagem de todos os sujeitos envolvidos.

$\mathrm{Na}$ primeira audiência judicial que acompanhei no Rio de Janeiro, os evangélicos, que foram processados por publicar um jornal (de pequena circulação) com ataques a religióes de matrizes afro, ao me verem falando com a advogada da outra "parte", recusaram-se a conversar. Os conflitos têm lados. Ao ouvir a versão de um nem sempre se consegue acessar o outro. É um dado etnográfico, náo um juízo de valor. Decidir de que lado estamos, tal como nos lembra Howard Becker (1977), ajuda a pensar os dilemas políticos, epistemológicos e éticos na pesquisa a partir do conflito, mas isso não pode significar um embate entre "achismos" - você acha isso e eu acho aquilo - tal como as falas nativas operam. Em artigo que publiquei com Jacqueline Muniz (2021), discutimos os limites de se fazer pesquisa e ser militante, no campo da segurança pública e dos direitos humanos, chamando a atenção para o fato de que a negociação entre os papéis de

12 Não posso deixar de registrar que nos vídeos que circularam com os terreiros sendo destruídos por "traficantes evangélicos" as falas são acompanhadas da presença de armas. Considero muito difícil lidar com esse fato numa perspectiva dialógica. Há uma imposição de força e nenhuma situação de dialogia. Trata-se de uma situação etnográfica muito distinta da que o autor se refere sobre os jovens evangélicos da periferia de Salvador, que teriam críticas ao candomblé. Não estamos diante do mesmo "fato etnográfico" (Peirano, 2008). 
militante e pesquisador(a) requer explicitação das posições políticas e rigor metodológico nos procedimentos de seleção, compilação e tratamento das evidências empíricas.

Reconhecer que a orientação cristã é eurocêntrica não é uma categoria de acusação, mas outro dado da pesquisa de campo ${ }^{13}$. Isso não significa ignorar a existência de evangélicos que lutam contra o racismo ou que participam de movimentos de direitos humanos, mas destacar qual é a variável que influencia e afeta as narrativas do contexto no qual estou inserida. A presença de pastores e pastoras que militam junto aos afrorreligiosas é um fato que não altera a hegemonia da matriz racial cristã. Relembro aqui uma fala de um pastor em um dos muitos eventos de caráter pluri-religioso de que participei. Ele dizia o quão difícil era para ele estar caminhando junto aos afrorreligiosos (todos paramentados). Era cobrado pelos seus discípulos e se cobrava, afinal aprendeu a crer que ali havia a manifestação do demônio. Ele, um homem negro, em cuja família havia pessoas da umbanda, disse que estava ali apenas por consciência política, pela importância da garantia dos direitos, mas seu coração estava em outro lugar. Essa impossibilidade de troca - afetiva/cognitiva - evidencia os limites da construção de um diálogo pluri-religioso. $\mathrm{O}$ pastor pode até ir ao evento contra a intolerância religiosa, mas seu rebanho fica no mesmo lugar...

${ }^{13}$ Considero aqui como os evangélicos se apresentam como o "verdadeiro" povo eleito por Deus e de que modo isso se articula com profecias bíblicas para produzir políticas racializadas de uma única humanidade (branca, cristã e universal). Ver Almeida (2019).

Debates do NER, Porto Alegre, ANo 2 I, N. 4O, P. 2 I I-234, AGo./DeZ. 202 I 


\section{A Dimensáo ReLigiosa}

As fronteiras entre a religiáo e a política, a partir da perspectiva das matrizes afro, foram exploradas por mim em trabalhos anteriores (Miranda, 2010, 2012, 2014, 2015, 2018a, 2018b), concordando com os argumentos de Paula Montero, de Ari Pedro Oro, de Emerson Giumbelli, dentre outros, de que o espaço público no Brasil sempre foi marcado pela presença do religioso. Nesse sentido, as interpretaçôes sobre o que é a laicidade, o secularismo e a tolerância têm sentidos bastante diferenciados se pensarmos de modo comparativo. Paula Montero nos traz o contraste entre o Brasil e a França para demonstrar como o debate sobre essas categorias evidencia que estamos diante de uma "forma (moderna) de sensibilidade e de governabilidade" para tratar da regulaçáo política do religioso. Ao perguntar qual a especificidade brasileira diante dessas questóes já consideradas "clássicas", a autora dialoga com meu artigo para salientar como o sentido histórico da "intolerância" se inverteu - "se no passado a noção de "tolerância" questionava a ação do Estado na regulação da coexistência entre as religióes, hoje essa categoria é mobilizada para exigir que o Estado regule essa relaçáo".

Ao se tornar ela própria um objeto de disputa, a noção de "tolerância" náo pode ser pensada como portadora de um conteúdo normativo próprio, já que seu sentido depende do contexto. Paula Montero conclui que o "uso político (da tolerância) pelas religiôes afro no Brasil e islâmicas na Europa revelam sua inadequação para enfrentar as tensóes inerentes às relaçốes entre duas expectativas igualmente estimadas: a tolerância e a liberdade religiosa”.

É a partir da discussão sobre tolerância e intolerância, tomando por base os casos de agressōes que sofrem as religióes afro, que tenho me debruçado para pensar, em uma perspectiva multidimensional, as questóes que envolvem o cenário de conflitos religiosos no Brasil, partindo da pesquisa no Rio de Janeiro e, posteriormente, em outros estados. O objetivo de ampliar o campo empírico é exatamente compreender os conflitos entre religiáo e política como foco de nossa reflexâo de que "os riscos do conservadorismo e extremismo religioso sobre os direitos" não podem ocultar "os interesses 
não propriamente doutrinários que movimentam essas disputas”. Alagoas e Sergipe são exemplos muito relevantes, não tão explorados etnograficamente como a Bahia, porque permitem pensar duas situaçóes distintas. No primeiro, o governador pediu desculpas formais pela destruição de terreiros ocorrida em 1912, no episódio conhecido como Quebra de Xangô (Miranda, 2021), e a partir daí se tornou visível ao país a mobilização dos terreiros no estado. Já em Sergipe têm ocorrido reiterados casos de apreensão de atabaques pela Polícia Militar do Estado, numa ação que contraria a orientação dada pelo Ministério Público estadual (Almeida, 2021). Essas controvérsias permitem evidenciar que as fronteiras entre a religião e a política são muito porosas e mutantes. Em todas estamos diante de violaçóes, mas os contextos são distintos do que acontece no Rio de Janeiro.

Observar as mobilizaçóes dos afrorreligiosos na defesa da garantia de direitos tem permitido perceber um deslocamento nas discussóes sobre religião. A novidade está no fato de que essas mobilizaçóes por direitos civis trazem para o centro do debate a dimensão das desigualdades jurídicas e das relaçóes étnico-raciais - e a forma como os adeptos dos terreiros passaram a acionar essas narrativas - que na atualidade constituem o campo religioso brasileiro, tal como ressaltou Elina I. Hartikainen.

Minha perspectiva não é defender este ou aquele posicionamento das distintas matrizes, tampouco de argumentar se o termo mais adequado é, ou não, intolerância/racismo religioso. Compreendo o argumento trazido por Ivanir dos Santos na defesa do uso do termo intolerância religiosa e não de racismo religioso, mas saliento que sua posição está associada ao modo pelo qual ele conduziu (e segue conduzindo) os trabalhos da Comissão de Combate à Intolerância Religiosa (CCIR) e da Caminhada em Defesa da Liberdade Religiosa numa direção de produção de "diálogo inter-religioso". Essa escolha significa se voltar para a interação com outros segmentos religiosos, em especial, os majoritários. Eu, que acompanho e participo desse movimento desde sua fundaçáo, em 2008, percebo o descontentamento de muitos representantes de matrizes afro, vários foram progressivamente deixando esse espaço político em busca de outras parcerias ou para dar continuidade aos trabalhos que já realizavam. 
O fenômeno ganhou visibilidade, mas não foram produzidas estratégias para a construção de uma agenda de ativismo e institucionalização dos movimentos, como Ari Pedro Oro analisa no caso do Rio Grande do Sul, que é anterior à criação da CCIR, com lógicas distintas das tradicionais federaçôes de umbanda e candomblé ${ }^{14}$.

O texto de Fátima Tavares enseja instigantes perguntas sobre os efeitos desse modelo de "diálogo inter-religioso". A autora traz para a reflexão a centralidade atual do debate acerca do "racismo religioso", ocorrido durante a realizaçáo da 6a REA (Reuniáo Equatorial de Antropologia), em Salvador (2019), em contraposição à fala que Ivanir dos Santos realizou durante a 32a RBA (Reunião Brasileira de Antropologia), no Rio de Janeiro (evento virtual - 2020). Ela questiona a alegada existência de um "acordo das lideranças cariocas" para a não inclusão da palavra "intolerância" no nome da Caminhada, o que teria possibilitado a adesão de diferentes comunidades religiosas ao movimento. Fátima, na posição de mediadora da sessão, apresentou notícias e reflexôes que evidenciavam uma dissonância sobre a posiçấo de Ivanir e concluiu afirmando que "nos caminhos do racismo religioso em Salvador, a política dos terreiros me parece seguir na direção apontada por Miranda".

A autora lembra ainda que, em Salvador, as atividades no espaço público - as Caminhadas - existem desde 1998. Esse marco é importante porque permite complexificar a ideia de que o ativismo está associado à vitimizaçấo dos terreiros nos anos 2000. Ao contrário, permite reforçar que o ativismo estava presente de forma organizada desde antes. O que muda é que os conflitos contemporâneos possibilitam a emergência de novas formas de ocupar o espaço público, de modo que a reivindicação do reconhecimento dos direitos de religiáo se dê enquanto tal e não apenas pela chave da "cultura". Esse fato é muito importante porque trata de uma controvérsia muito forte

${ }^{14}$ Lembro do trabalho de Ávila (2009) sobre o CEDRAB, fundado em 2002, que colocou em seu estatuto a eleição de mandatos para se diferenciar das federaçôes que são constituídas em torno de uma liderança religiosa, que se perpetua no poder, tal como seria a entronização nos terreiros.

Debates do NER, Porto Alegre, ANo 2I, N. 4O, P. 2 I I-234, Ago./Dez. 202 I 
e presente nos debates afrorreligiosos: a defesa dos direitos é pelo direito de existir, pela manifestação religiosa ou pela manifestação cultural? A única resposta possível a isso é: depende do contexto de pesquisa.

Fátima Tavares retoma um ponto fundamental do meu artigo - a crítica "a acepção corrente que desconsidera a ação política dos afrorreligiosos" ${ }^{\prime 15}$ - e sinaliza como é o reconhecimento do "pleno direito" que mobiliza agenciamentos específicos. A presença dos orixás no espaço da política em Salvador se mistura com as modalidades tradicionais de articulação política. Para ela há uma aproximação da minha abordagem com a defendida por Goldman (2000) em relação à problematização da política como um domínio externo à experiência dos nossos interlocutores. Devo explicitar que concordo em pensar a política a partir do sentido dos próprios agentes e os modos através dos quais articulam entre si outras dimensóes da experiência. Saliento apenas que, em meu artigo, procuro argumentar que os próprios agentes fazem essa articulaçáo política, mas segue havendo um não reconhecimento dos outros atores, o que inclui certos pesquisadores, que insistem em cobrar do povo de santo uma organização política "embranquecida”, capaz de enfrentar quixotescamente o "outro lado". Meu intuito não é produzir rótulos, mas argumentar que a "política dos terreiros" coexiste com as políticas "cristofascistas" numa relação assimétrica, sendo que a última se apresenta de forma hegemônica no contexto atual, produzindo efeitos concretos sobre os corpos e subjetividades dos atores de opressão e imposição de violência física e moral. Daí a importância de acionar as vias processuais do judiciário para tentar produzir um reconhecimento coletivo de direitos, que implica o Estado como parte do conflito, por ser ator chave na regulação do religioso.

A perspectiva de algum "diálogo inter-religioso", presente nos textos de Ivanir dos Santos e de John F. Collins, foca na interação entre sujeitos

15 Mariana Ramos de Morais questiona por que os autores que falam da "falta" de organização política não estão referidos no meu artigo. Explico que nunca foi um objetivo fazer um levantamento do que considero ser um juízo de valor, mas apontar como os atores com os quais interajo têm efetivamente se mobilizado e organizado politicamente. Penso que esta pergunta pode ser o mote para outro artigo, já que implicaria em revisitar a literatura das Ciências Sociais brasileiras. 
que estão fora do campo das religióes que se representam como matrizes afro. O que tenho tentado compreender é como a "política dos terreiros", em si, demanda outro tipo de debate inter-religioso, na medida em que reconhece e permite a interação de um número diversificado de expressões afrorreligiosas que, apesar de serem parecidas porque foram conformadas no Brasil, possuem diferenças em organização social, práticas e cosmologias. Refiro-me explicitamente às disputas faccionais e internas no campo das matrizes afro, que reciprocamente se acusam de desuniáo, mas que diante da gravidade dos eventos enfrentados têm se disposto a constituir espaços dialógicos e estratégias de ação que fujam da exposição das vítimas.

O texto de Stephen Selka identifica que o artigo aponta uma "urgência ética" do modo pelo qual profissionais e ativistas precisam olhar essas tensóes e conflitos, tomando em conta o seu contexto mais amplo. É exatamente por isso que considero que não há uma confusão sobre a distinção entre religião privada e interesses públicos. Essa distinção rende pouco analiticamente para pensar os terreiros, que não se encaixam na discussão público $x$ privado. Historicamente, essa separação nunca se constituiu, já que são tradições religiosas cujos templos são espaços abertos e de trânsito permanente. $\mathrm{O}$ mesmo espaço pode ser a residência do sacerdote e um espaço sacralizado simultaneamente. Concordo que a ideia de "patrimonialização" do Candomblé traz aos terreiros outros atores, mas penso que essa interface entre os terreiros de candomblé e a esfera pública é muito mais complexa, porque a aposição de um despacho na via pública acaba por sacralizar um espaço até então laico. Não é o espaço em si que importa, mas a intervenção efêmera naquele local que expõe as fronteiras móveis do dentro/fora, público/privado, sagrado/secular.

Concordo com o argumento do autor que para pensar a "política dos terreiros", como algo que "constrói e expande os tipos de interfaces públicas que sempre existiram nas comunidades de candomble’”, o trabalho etnográfico de Elina Hartikainen (2018) fornece boas perguntas. Como os religiosos usam e se apropriam da linguagem do respeito e outros discursos democráticos, o que inclui as categorias de intolerância religiosa e do racismo religioso, no contexto do terreiro do candomblé, e quais são os efeitos sobre as relaçôes hierárquicas? Trata-se de um excelente campo a se explorar. 
Esse também é o eixo de interpretação de Mariana Ramos de Morais, que explora de forma genealógica não só como eu tenho apontado a emergência de "três categorias políticas" mobilizadas pelo movimento afrorreligioso ${ }^{16}$ - "intolerância religiosa", "racismo religioso" e "genocídio religioso do povo negro" -, como retoma uma discussão que foi fundante para a própria revista. Ao recuperar o artigo de Oro (1997), acerca de uma possível "inércia das religióes afro-brasileiras" face aos ataques evangélicos, a autora aponta brilhantemente como a diferença dos contextos de produção das análises influencia o resultado das pesquisas.

Mariana conclui que "o "povo de santo" sempre esteve na "rua", seja para saudar suas divindades e entidades ou para fazer as festas religiosas nos espaços públicos". Ao fazê-lo afirma que praticar uma religião é um ato político. Mostra, também, que as mudanças observadas desde 1997 até agora aconteceram pelo fato de que os atos contra a "intolerância religiosa" têm mobilizado uma capacidade aglutinadora de diferentes agentes do movimento afro-religioso. Relembra os anos 2000 como um marco classificador dos "ataques" contra as religióes afro-brasileiras (Silva, 2007), o que possibilitou que a expressão "intolerância religiosa” fosse acionada como uma categoria política na luta dos afro-religiosos por seus direitos (Miranda, 2010).

A contextualização feita por Mariana nos permite pensar que, sim, é possível afirmar que há uma perseguição histórica às tradiçôes afro. Algo que começou como consequência do tráfico Atlântico mercantil de negros/as, oriundos de distintas regiôes da África. Mas, para compreender os efeitos e as agências dos sujeitos, é preciso entender que as perseguições não atingiam, e seguem não atingindo, a todos da mesma forma. No passado, as práticas de ataque aos malês (muçulmanos) se distinguiram das que atingiram as outras

${ }^{16}$ A autora explica que ele é entendido "como um movimento social formado por entidades representantes das religiôes afro-brasileiras, que apresenta diferentes frentes de atuação. Essas frentes se modificaram ao longo dos séculos XX e XXI, mantendo como seu objetivo primeiro a busca pela garantia da prática religiosa de seus representados." A autora opta por grafar afro-religioso com hífen para demarcar a relevância do afro nessa ação política.

Debates do NER, Porto Alegre, ANo 2 I, N. 40, P. 2 I I-234, Ago./Dez. 202 I 
etnias (iorubás, jejes, bantus). Hoje, as violaçóes também não afetam a todos da mesma forma. É por meio da pesquisa etnográfica que podemos perceber as diferenças e as marcas da demonização e perseguição contemporâneas. $\mathrm{O}$ protagonismo dos afrorreligiosos na defesa de sua "africanidade", na valorização da autoestima dos sujeitos e de seus modos de vida "tradicionais", se contrapóem ao modelo urbano-cristáo que tem prevalecido nas grandes cidades brasileiras. A resposta política que as religióes afro-brasileiras têm apresentado a essas violaçôes é que elas sempre estiveram nas ruas e váo continuar. A resposta religiosa pode ser expressa pelo oriki "Exu matou um pássaro ontem, com uma pedra que só jogou hoje."

\section{REFERÊNCIAS}

ALMEIDA, Rosiane Rodrigues de. Quem foi que falou em igualdade? Rio de Janeiro: Autografia, 2015.

ALMEIDA, Rosiane Rodrigues de. A luta por um modo de vida: as narrativas e estratégias de enfrentamento ao racismo religioso dos membros do FONSANPOTMA. 2019. Tese (Doutorado em Antropologia) - Faculdade de Antropologia, Universidade Federal Fluminense, Rio de Janeiro, 2019.

ALMEIDA, Rosiane Rodrigues de. Racismo Consentido: Análise dos Casos de Apreensão de "Instrumentos Sonoros de Matriz Africana" em Sergipe. In: MIRANDA, Ana Paula Mendes de; OLIVEIRA, Ilzver de Matos (org.). Pesquisa empirica aplicada ao Direito. Perspectivas teóricas e metodológicas sobre o reconhecimento de direitos. Rio de Janeiro: Telha, 2021.

ALMEIDA, Ronaldo de. Comentários ao artigo "A 'política dos terreiros' contra o racismo religioso e as políticas 'cristofascistas', de Ana Paula Miranda. Debates do NER, Porto Alegre, ano 21, n. 40, 2021. 
ÁVILA, Cíntia Aguiar de. Na interface entre religião e politica: Origem e práticas da congregação em defesa das religióes afro-brasileiras (CEDRAB-RS). 2009. Dissertação (Mestrado em Antropologia) - PPGAS/UFRGS, Niterói, 2009. BECKER, Howard S. Uma teoria da ação coletiva. Rio de Janeiro: Zahar, 1977. CEFAÏ, Daniel. La construction des problèmes publics. Définitions de situations dans des arènes publiques. Réseaux, v. 14, n. 75, p. 43-66, 1996. COLLINS, John. Interpretação equivocada (diferente) no Brasil: conexões escusas e críticas mal posicionadas no Rastafári e candomblé. Debates do NER, Porto Alegre, ano 21, n. 40, 2021.

GOLDMAN, Marcio. Uma teoria etnográfica da democracia: a política do ponto de vista do movimento negro de Ilhéus, Bahia, Brasil. Etnográfica, Lisboa, v. 4, n. 2, p. 311-332, 2000.

GIUMBELLI, Emerson. Para estudar a laicidade, procure o religioso. In: BÉLIVEAU, Verónica Giménez; GIUMBELLI, Emerson (org.). Religión, Cultura e politica en las Sociedades del siglo XXI. Buenos Aires: Biblos, p. 43-68, 2013.

GLUCKMAN, Max. Análise de uma situação social na Zululândia moderna. In: FELDMAN-BIANCO, B. (org.). Antropologia da Sociedade Contemporânea. São Paulo: Global, 1987.

HARTIKAINEN, Elina I. A politics of respect: Reconfiguring democracy in Afro-Brazilian religious activism in Salvador, Brazil. American Ethnologist, v. 45, n. 1, p. 87-99, 2018.

HARTIKAINEN, Elina I. Racismo religioso, discriminação e preconceito religios, liberdade religiosa: controvérsias sobre as relaçóes entre Estado e religião no Brasil atual. Debates do NER, Porto Alegre, ano 21, n. 40, 2021. MIRANDA, Ana Paula Mendes de. Entre o privado e o público: consideraçóes sobre a (in) criminação da intolerância religiosa no Rio de Janeiro. Anuário Antropológico, 2009-2, p. 125-152, 2010. 
MIRANDA, Ana Paula Mendes de. "A força de uma expressão: intolerância religiosa, conflitos e demandas por reconhecimento de direitos no Rio de Janeiro". Comunicaçóes do ISER, v. 66, p. 60-73, 2012.

MIRANDA, Ana Paula Mendes de. Como se discute Religião e Política? Controvérsias em torno da "luta contra a intolerância religiosa" no Rio de Janeiro. Comunicaçôes do ISER, v. 69, p. 10-23, 2014.

MIRANDA, Ana Paula Mendes de. "Motivo presumido: sentimento": identidade religiosa e estigmatização escolar no Rio de Janeiro. Dilemas: Revista de Estudos de Conflito e Controle Social, 1, p. 139-164, 2015.

MIRANDA, Ana Paula Mendes de. Intolerância religiosa e discriminação racial: duas faces de um mesmo problema público? In: SOUZA LIMA, Antonio Carlos de et al. (org.). A Antropologia e a esfera pública no Brasil: Perspectivas e Prospectivas sobre a Associaçáo Brasileira de Antropologia no seu $60^{\circ}$ Aniversário. Rio de Janeiro: E-papers/ABA publicaçóes, p. 329-363, 2018a.

MIRANDA, Ana Paula Mendes de. Manifestaçôes da intolerância religiosa no Rio de Janeiro: visibilidade, conflitos e demandas por reconhecimento de direitos na esfera pública. In: José Manuel Resende et al. (org.). (Con) Vivemos numa sociedade justa e decente? Críticas, envolvimentos e transformaçōes. 1 ed. Porto: Fronteira do Caos, p. 221-246, 2018 b.

MIRANDA, Ana Paula M. de. "Terreiro politics" against religious racism and "Christofascist" politics. Vibrant, Brasília, v. 17, p. 1-20, 2020.

MIRANDA, Ana Paula M. de. "Xangô Rezado Alto": mobilizaçóes políticas e ocupação de espaços públicos por afrorreligiosos em Maceió (AL). In: MIRANDA, Ana Paula Mendes de; OLIVEIRA, Ilzver de Matos; LIMA, Lana Lage da Gama (org.). As tramas da intolerância e do racismo. Rio de Janeiro: Telha, 2021. 
MIRANDA, Ana Paula Mendes de; CORREA, Roberta de M.; ALMEIDA, Rosiane Rodrigues. O "Renascimento" da Intolerância Religiosa e as Formas de Administraçáo Institucional de Conflitos no Brasil. In: Ricardo Perlingeiro (org.) Liberdade Religiosa e direitos humanos. Niterói: Nupej / TRF2, p. 111-146, 2019.

MIRANDA, Ana Paula M. de.; MUNIZ, Jacqueline. Dominio armado: el poder territorial de las facciones, los comandos e las milicias en el Rio de Janeiro. Revista Voces en el Fénix. v. 68, p. 44-49, 2018.

MIRANDA, Ana Paula M. de.; MUNIZ, Jacqueline. Um campo de experiências, afetaçóes e "achismos": dilemas e desafios metodológicos em pesquisas empíricas sobre criminalidade, violências, (in) segurança e ativismos. Runa, v. 42, n. 1, p. 21-41, 2021.

MIRANDA, Ana Paula Mendes de. A "política dos terreiros" contra o racismo religioso e as políticas "cristofascistas". Debates do NER, Porto Alegre, ano 21, n. 40, 2021.

MONTERO, Paula. Secularismo brasileiro à luz das categorias de "injúria" e "intolerância religiosa". Debates do NER, Porto Alegre, ano 21, n. 40, 2021. MORAIS, Mariana Ramos de. Políticas públicas e a fé afro-brasileira: uma reflexão sobre açôes de um Estado laico. Ciencias Sociales y Religión/Ciências Sociais e Religiāo, ano 14, n. 16, p. 39-59, 2012.

MORAIS, Mariana Ramos de. Intolerância, racismo e genocídio religioso do povo negro: pensando sobre as categorias afro-religiosas da "política dos terreiros". Debates do NER, Porto Alegre, ano 21, n. 40, 2021.

ORO, Ari Pedro. Neopentecostais ou afro-brasileiros: quem vencerá esta guerra?. Debates do NER, Porto Alegre, ano 1, n. 1, p. 10-36, 1997.

ORO, Ari Pedro. Políticas "cristofascistas" e "políticas de terreiros" no Rio Grande do Sul: a polêmica dos sacrifícios de animais nas religiôes de matriz africana. Debates do NER, Porto Alegre, ano 21, n. 40, 2021. 
PEREIRA, Luena Nascimento Nunes. Alteridade e raça entre África e Brasil: branquidade e descentramentos nas ciências sociais brasileiras. Revista de Antropologia, São Paulo, v. 63, n. 2, 2020.

PEIRANO, Mariza. Etnografia, ou a teoria vivida. Ponto Urbe, Săo Paulo, 2, 2008.

SANTOS, Ivanir dos. Desafios contemporâneos em prol da liberdade religiosa. Debates do NER, Porto Alegre, ano 21, n. 40, 2021.

SARTI, Cynthia. A vítima como figura contemporânea. Caderno CRH, v. 24, n. 61, p. 51-61, 2011.

SARTI, Cynthia. A construção de figuras da violência: a vítima, a testemunha. Horizontes Antropológicos, ano 20, n. 42, p. 77-105, 2014.

SELKA, Stephen. Candomblé público revisitado. Debates do NER, Porto Alegre, ano 21, n. 40, 2021.

SILVA, Vagner Gonçalves da (ed.). Intolerância Religiosa: impactos do neopentecostalismo no campo-religioso brasileiro. São Paulo: EDUSP, 2007.

SIMMEL, Georg. Conflict \& The web of group-afiliations. New York: The Free Press, 1964.

SOARES, Luiz Eduardo. Dimensóes democráticas do conflito religioso no Brasil: a guerra dos pentecostais contra o afro-brasileiro. In: SOARES, Luiz Eduardo. Os dois corpos do presidente e outros ensaios. Rio de Janeiro: Relume Dumará, 1993.

SOARES, Luiz Eduardo. Revoluçóes no campo religioso. Novos Estudos, São Paulo, v. 38, n. 1, jan./abr., p. 85-107, 2019.

TAVARES, Fátima. Sobre a "política dos terreiros" em Salvador: comentários ao texto de Ana Paula Mendes de Miranda. Debates do NER, Porto Alegre, ano 21, n. 40, 2021. 
TOURAINE, Alain. Production de la société. Paris: Éditions du Seuil, p. 347-89, 1973.

VAN VELSEN, Jaap. A análise situacional e o método de estudo de caso detalhado. In: Feldman-Bianco, B. (org.). Antropologia da Sociedade Contemporânea. São Paulo: Global, 1987.

Recebido em: 15/09/2021

Aprovado em: 15/09/2021 
ARTIGOS 